Article

\title{
Safety Issues Regarding the Detection of Antibiotics Residues, Microbial Indicators and Somatic Cell Counts in Ewes' and Goats' Milk Reared in Two Different Farming Systems
}

\author{
Georgios Rozos ${ }^{1}$, Ioannis Skoufos ${ }^{1}$, Konstantina Fotou ${ }^{1}$, Athanasios Alexopoulos ${ }^{2}$, , Anastasios Tsinas ${ }^{1}$, \\ Eugenia Bezirtzoglou $^{3}\left(\mathbb{D}\right.$, Athina Tzora ${ }^{1}(\mathbb{D})$ and Chrysoula (Chrysa) Voidarou ${ }^{1, *}$ \\ 1 Department of Agriculture, School of Agriculture, University of Ioannina, 47100 Arta, Greece; \\ clevervet@hotmail.com (G.R.); jskoufos@uoi.gr (I.S.); kfotou@uoi.gr (K.F.); actsinas@uoi.gr (A.T.); \\ tzora@uoi.gr (A.T.) \\ 2 Laboratory of Microbiology Biotechnology \& Hygiene, Department of Agricultural Development, Democritus \\ University of Thrace, 68200 Orestiada, Greece; alexopo@agro.duth.gr \\ 3 Laboratory of Hygiene and Environmental Protection, Medical School, Democritus University of Thrace, \\ 68100 Alexandroupolis, Greece; empezirt@yahoo.gr \\ * Correspondence: xvoidarou@uoi.gr
}

check for updates

Citation: Rozos, G.; Skoufos, I.; Fotou, K.; Alexopoulos, A.; Tsinas, A.; Bezirtzoglou, E.; Tzora, A.; Voidarou, C. Safety Issues Regarding the Detection of Antibiotics Residues, Microbial Indicators and Somatic Cell Counts in Ewes' and Goats' Milk Reared in Two Different Farming Systems. Appl. Sci. 2022, 12, 1009. https: / /doi.org/10.3390/app 12031009

Academic Editor:

Alessandra Durazzo

Received: 7 December 2021

Accepted: 17 January 2022

Published: 19 January 2022

Publisher's Note: MDPI stays neutral with regard to jurisdictional claims in published maps and institutional affiliations.

Copyright: (C) 2022 by the authors. Licensee MDPI, Basel, Switzerland. This article is an open access article distributed under the terms and conditions of the Creative Commons Attribution (CC BY) license (https:// creativecommons.org/licenses/by/ $4.0 /)$.

\begin{abstract}
Milk samples of ewes' and goats' unprocessed milk were collected from milk tanks from various farms in Epirus, Greece and classified in two groups according to the type of farming Analyses of the samples included microbial inhibition assays to detect the presence of antibiotic residues, isolation of Staphylococcus aureus and Escherichia coli strains as microbiological indicators for susceptibility to antimicrobial medicines, Somatic Cells and Coagulase Negative Staphylococci (CNS) counts. These findings were correlated with each other as well as to the stage of the lactation period and to the type of the farming practices. Monitoring of bulk tank milk for residues of antibiotics should be performed after heating of the milk, on a regular basis, and should include at least two different tests. The results point out that the type of farming affects the CNS counts as well as the prevalence of residues in the milk. Furthermore, the inverse correlation between CNS counts and prevalence of residues of antibiotics suggests a possible protective role of CNS. Resistance of the bacterial indicators to antibiotics was random and relatively rare, perhaps acquired in past due to misuse of antibiotics, turning the indicator microorganisms to reservoir of resistance.
\end{abstract}

Keywords: milk; antibiotic; residues; Staphylococcus aureus; Escherichia coli; Coagulase Negative Staphylococci (CNS)

\section{Introduction}

In the past, sheep and goat farming has been considered as an "inferior" form of animal husbandry and a sign of economic underdevelopment. This was especially true for the Mediterranean countries. The main reasons for this were that in large areas of these countries sheep and goat farming was an important occupation of the poorest part of the rural populations and the simplistic methods by which these animals were handled. Practically most of the farmers were herding their animals in a manner much similar to that in classical antiquity. Nevertheless, things have changed during the last two decades [1-4]. The markets acknowledged the organoleptic and the nutritional value of the sheep and goat's dairy products and the demand for these products increased [3,5-9]. Many of these products have received the characterization PDO (Protected Designation of Origin) which adds commercial value $[1,7,10]$. The governments tried, through subsidizations and other economic means, to support the farmers, and the dairy industry has also invested on these farms. It is not a surprise that the landscape in sheep and goat farming has changed dramatically. New farms have emerged with better facilities, automatization, genetically 
improved livestock and with well implemented nutritional practices. On the other hand, in mountainous and remote areas many farms still function in a traditional manner and thus a phenomenon of two-speed farming has been observed ([11] \& personal data). The impact of this differentiation on various parameters that determine the quality and the safety of the milk has not been thoroughly investigated. Subclinical mastitis is the most prevalent health ailment in these herds. The disease although has no clinical signs but is of great importance due to the reduction of the milk yield up to $8 \%$ per animal as well as the technological defects of the final product [12]. There is a consensus in scientific literature that the Coagulase Negative Staphylococci (CNS) are among the main causative agents of subclinical mastitis in small ruminants and account for more than $65 \%$ of cases $[13,14]$. However, quite a few researchers agree that some CNS can play a protective role to the health of the udder $[15,16]$. This effect is probably strain and species specific and wherever it is observed one should expect a reduction in the use and consequently in the misuse of antibiotics, an aspect neither clearly understood nor investigated. The misuse of antibiotics in some farms is a fact. As Betran-Martinez (2014) [17] puts it, most medicines are registered for cows and relatively few are registered for mastitis treatment in small ruminants, yet most veterinarians use these drugs licensed for bovines, empirically in goats and sheep. This results to deviating dosage issues (overdose or underdose), a problematic therapeutic efficacy and an unknown withdrawal period [17]. In some countries the same active substance (usually a $\beta$-lactam) is used not only in the treatment of mastitis but also in many other clinical ailments (e.g., diarrhea, skin lesions, etc.). These conditions lead to residues of antibiotics in the milk.

Residues of antibiotics are not affected by the thermal treatment of the milk. Neither the heat treatment nor any other process of the milk decomposes or deactivates the residues and therefore they accumulate in the food chain and reach the consumer causing allergies, toxicities, cancer, mutagenesis and antimicrobial resistance to the intestinal microbiome $[18,19]$. These residues cause also significant technological failures with consequent financial loses in the dairy industry and particularly in the fermentation processes [20]. According to the EU legislation, milk containing residues of antibiotics should be discarded as category $2 \mathrm{ABP}$ (Animal by-products) [21,22].

It follows that it is of utmost importance to detect the residues and the best place to undertake that is at the production site, in the milk of the bulk tank of the farm, before the milk reaches the dairy.

In the market quite a few commercial kits are available. They are sensitive to different groups of antimicrobial substances and their function is based on the same principle, that is the inhibition of bacterial growth in the presence of antimicrobial residues. Usually, the indicator organism is Bacillus stearothermophilus while bromocresol serves as the color index (remains purple in positive samples and turns yellow in the negative ones) $[20,23,24]$.

However, one thing is a result, and another thing is the biological interpretation of this result. The inhibition of bacterial growth can be affected by other factors which inhibit the bacterial growth and eventually lead to false positive results. Such factors are (i) the presence of natural substances in the milk such as the bacteriocins, (ii) higher somatic cells content of the milk and (iii) presence of detergents and disinfectants in the milk. It is obvious that all these three factors are closely related to the management of the farm and it is for these reasons that any positive results should be further confirmed by more sophisticated methods. False negative results occur in cases of test failure or in cases where the implicated antibiotic residue is out of the range of detection of a particular test [20,25-27].

This study is an attempt to comparatively investigate the correlation between type of farming and prevalence of antibiotics residues to the bulk tank milk. Furthermore, this study surveys the possible protective role of CNS to the udder as indicated by the Somatic Cells Count (SCC) as well as the prevalence of antibiotic residues. Although the validity of the tests used is also examined, it is theses correlations that will put the biological 
interpretation of these tests in another more accurate perspective and consequently improve the evaluation of the quality of the raw sheep and goat milk.

\section{Materials and Methods}

\subsection{Study Area-Milk Samples}

Sampling took place in the rural area of Epirus region and in western Greece, and more specifically in the regional unit of Arta and Preveza (Epirus) as well as in Amphilochia in the regional unit of Aitoloakarnania. Dairy farmers were identified with the collaboration of the regional Veterinary agencies. These areas, where the current survey took place, are mountainous with intense slope differences and a rather poor road network. The distance of many farms from the capital of the area is more than $70 \mathrm{~km}$. In these areas two types of farming are observed and we classified them as Group A farms and Group B farms.

The characteristics of each type of farming are analyzed as follows:

Group A: This is the group of more "intensive" breeding. Most of the animals are sheep belonging to Frizarta breed or to Karagouniko breed or to various cross breeds but mainly Boutsiko with Frizarta (25\%). The caprine population did not exceed $5 \%$ of the herd population while the average size of the herd varied between 250 and 400 animals. Milking was performed with the aid of milking parlours. The animals were housed and they usually grazed for some hours daily on pastures adjoining the unit. They were fed supplements of concentrates and hay. Sheep energy requirements in this system were estimated to be supplied $53 \%$ from grazing and $47 \%$ from supplementary feeding (of which $41 \%$ concentrates and $6 \%$ roughage). The respective values for goats were $73 \%$ from grazing and $27 \%$ from concentrates.

Group B: This is the group of more traditional farming practices. In these farms the majority of the animals belonged to cross breeds mainly between different local mountain sheep breeds or in some cases with Karagouniko or Frizarta breeds. Caprine population belonged to indigenous breeds (Capra Prisca) and reached 10\% of the herd while the average size of the herd varied from 75 to 150 animals. More than $75 \%$ of these farms were located in high altitude remote areas. Milking was performed manually. The animals were housed during the night, they were grazing all day long in pastures located in the surrounding area of the holdings, receiving a small amount of concentrates at dusk.

It is self-evident that these characteristics of the two groups of farms were shaped over time by various factors among which the most important was the exact geographical location of the farm (the more remote, the more traditional).

In both groups milking took place twice a day and the milk was placed in cooling bulk tanks with temperatures adjusted to $4-6{ }^{\circ} \mathrm{C}$. Each farm had its own bulk tank.

From each group 20 farms were selected randomly and samples for the purposes of the present study, were collected in the morning and contained the milk from the milking of the last $12 \mathrm{~h}$. The main criterion for a farmer to be included in the current survey was his ability to understand the purpose of this study and his willingness to participate in the survey.

Samples were collected throughout the milking period, that is from March till August 2020 (1 sample per month from every tank, 6 samples in total from every tank). $1000 \mathrm{~mL}$ of raw unprocessed milk were collected aseptically into sterilized containers. All samples were transported in isothermal boxes with ice and within $2 \mathrm{~h}$ from the collection were subjected to the laboratory in the Department of Agriculture, in Arta.

The overall workflow for samples collection and analyses performed is presented in Scheme 1. 


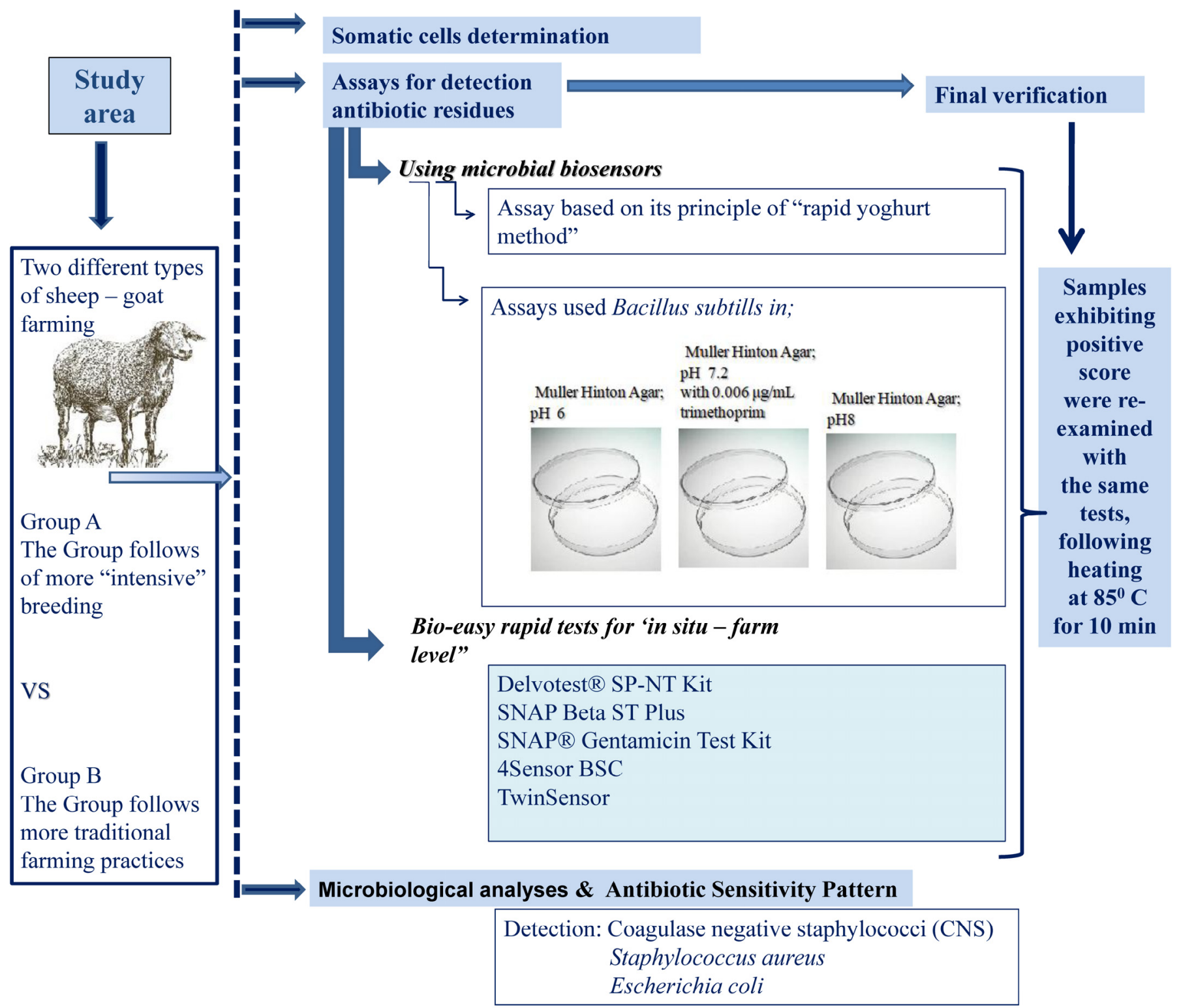

Scheme 1. Schematic analysis of the workflow.

\subsection{Screening of Milk for Somatic Cells}

Somatic cells were determined using a conventional instrument, cell counter FOSSOMATIC $^{\text {TM }}$ (MilkoScan, Foss Electric, Hillerød, Denmark). The analyses were performed in duplicate. The SCCs were transformed into logarithmic forms before performing statistical analysis.

\subsection{Assays for Detection Antibiotic Residues}

\subsubsection{Using Microbial Biosensors}

Assay Based on Its Principle of the "Rapid Yoghurt Method"

A slight modification of the "'rapid yoghurt method", proposed by Yamani et al. (1999) [28] was used in our study, for the detection of antibiotics and other inhibitory substance. First, 10-15 gr starter granules containing Streptococcus thermophilus and Lactobacillus delbrueckii ssp. bulgaricus [CH-1 (Chr. Hansen, Hørsholm, Denmark)], were added to $0.5 \mathrm{~L}$ of fresh UHT milk. The inoculated milk was incubated at $40{ }^{\circ} \mathrm{C}$ for $12 \mathrm{~h}$ until acidity reached $100^{\circ}$ dormice. Afterwards, it was immediately transferred to the refrigerator. The obtained culture is known as mother culture (stored at $5^{\circ} \mathrm{C}$ ). An amount of $10 \mathrm{~mL}$ of each 
milk sample was homogenized and heated to $80^{\circ} \mathrm{C}$ for $3 \mathrm{~min}$ in a warm water bath. The temperature of samples was rapidly reduced to $42-43{ }^{\circ} \mathrm{C}$ and $1 \mathrm{~mL}$ of fresh well-stirred lactic inoculum (homogenized) was mixed with the milk sample. Next, $0.5 \%$ methylene blue $(0.3 \mathrm{~mL})$ was added to the samples, subsequently incubated at $43^{\circ} \mathrm{C}$ for $2 \mathrm{~h}$, and color variations in the samples were checked. A positive control was made by serial dilution of sterile penicillin G, $2.4 \times 106$ IU (Pfizer Inc., New York, NY, USA), to give a final solution of $0.03 \mathrm{IU} / \mathrm{mL}$. UHT milk was used as a negative control. Antibiotic-free samples showed white color after incubation because of the growth of starter bacteria, while blue color indicates a positive milk sample containing more than $0.03 \mathrm{IU} / \mathrm{mL}$ of the inhibitory substance. Moreover, the presence or absence of lactic coagulation in samples was obvious from their consistency. The acidity of suspicious samples was about $10^{\circ} \mathrm{D}$ less than that of natural milk indicating the presence of antibiotics or other inhibitory compounds. The samples with $\mathrm{pH}>5.3$ were considered positive samples [29]. During all the experiment, positive and negative controls were performed and remained available for a better interpretation of the results.

\section{Assays Used Bacillus Subtills}

An inoculum of $0.1 \mathrm{~mL}$ of spores' suspension of Bacillus subtilis (Cell Line 6633Crosstex International, Inc., Industrial Markets, New York, NY, USA) was transferred and introduced to $100 \mathrm{~mL}$ of Muller-Hinton (MH, Difco, Göteborg, Sweden) agar or Nutrient Agar (NA, Merck, Darmstadt, Germany), before solidification and the mixture-molten agar was poured into petri dishes and allowed to solidify at room temperature. Muller Hinton Agar assay plates with B. subtilis were created as follows: for every milk sample, 3 plates in Muller Hinton Agar; $\mathrm{pH}$ value 6; $\mathrm{pH}$ value 7.2 with $0.006 \mu \mathrm{g} / \mathrm{mL}$ trimethoprim and $\mathrm{pH}$ value 8 (totally 3 plates for each testing milk sample). Blank disks (10 $\mathrm{mm})$ of filter papers (Whatman ${ }^{\circledR}$-Merck) were totally soaked into milk samples and placed on the surface of the above agar medium containing B. subtilis using sterile forceps. In addition to the test disk, a control blank disk was also added in every agar plate. The petri plates were incubated at $36 \pm 1{ }^{\circ} \mathrm{C}$ for $36 \mathrm{~h}$, under aerobic conditions. The presence of antibiotic residues (positive results) was indicated by formation of transparent zone around the disk plates (the diameter of the inhibition clear zone appeared more than $12 \mathrm{~mm}$ ) [30].

\subsubsection{Bio-Easy Rapid Tests for 'In Situ-Farm Level'}

- $\quad$ The Delvotest ${ }^{\circledR}$ SP-NT Kit (DSM, Food Specialties, The Netherlands), which is a non-specific microbial inhibitor test.

- $\quad$ SNAP Beta ST Plus-Detection Level (at or below), ppb (Detects more beta-lactam residues including cephalexin at or below established maximum residue limits). The specific tests are enzyme-linked receptor binding assays that detect antibiotics in raw milk. (IDEXX Laboratories Inc., Westbrook, ME, USA).

- $\quad$ SNAP ${ }^{\circledR}$ Gentamicin Test Kit (IDEXX B.V., Hoofddorp, The Netherlands). An enzymelinked immunoassay designed to detect gentamicin residues in raw, commingled milk. In addition, the manufacturer ensures that residues from common mastitis antibiotic are within regulatory limits.

- $\quad$ 4Sensor BSC [Unisensor Diagnostic E., Seraing (Ougrée)—Belgium]. A multiplex dipstick assay for the rapid and simultaneous detection of beta-lactam antibiotics, tetracyclines, streptomycin and chloramphenicol in milk. 4Sensor is a competitive test involving specific receptors and generic monoclonal antibodies in one single operation.

- $\quad$ TwinSensor [Unisensor Diagnostic E., Seraing (Ougrée)—Belgium]. A competitive test involving specific receptors with high affinity for Betalactams and Tetracyclines molecules, in one single operation, specific to the European Union maximum residue limits (KIT020).

All the above tests were conducted according to each manufacturer's instructions and data interpretations were performed according to the manufacturer's instructions. 


\subsubsection{Final Verification of the Detection of Residues of Antibiotics in Milk}

Samples exhibiting inhibition clear zone on the assay plates or with a positive score to the tests described in Section 2.3.2, were repeatedly tested with the same tests, following heating at $85^{\circ} \mathrm{C}$ in a water bath for $10 \mathrm{~min}$ prior to the test. The samples were scored as positive when the diameter of the inhibition clear zone appeared more than $12 \mathrm{~mm}$ on the assay plates or according to the manufacturer's instructions for the tests described in Section 2.3.2. Although the commercial tests require heating prior to testing, we heated the sample again in case that the first heating failed to neutralize any natural antimicrobials expected to be contained in a complex matrix such as milk.

\subsection{Microbiological Analyses}

Microbiological analyses were performed on the obtained milk samples as follows:

- Detection of Staphylococcus sp. [31-33]: $1 \mathrm{~mL}$ of milk samples was enriched in $9 \mathrm{~mL}$ of Mueller-Hinton broth supplemented with $6.5 \% \mathrm{NaCl}$ (Oxoid Ltd., Basingstoke, UK). Incubation at $37^{\circ} \mathrm{C}$ for $20 \mathrm{~h}$ followed and $1 \mathrm{~mL}$ was enriched in $9 \mathrm{~mL}$ of Tryptone Soya broth with $10 \% \mathrm{NaCl}$ and $1 \%$ sodium pyruvate (HiMedia Labs, Einhausen, Germany). Incubation followed at $35{ }^{\circ} \mathrm{C}$ for $20 \mathrm{~h}$ and then the enrichment broth was inoculated onto Baird-Parker agar (Oxoid Ltd., Basingstoke, UK) containing 30\% egg yolk with $1 \%$ tellurite (Oxoid Ltd., Basingstoke, UK) and mannitol salt phenol red agar (Merck, Darmstadt, Germany) plates. Another quantity of milk sample was inoculated into $5.0 \%$ Sheep Blood Agar [SBA, (Becton Dickinson, Sparks, NV, USA)] plates. Anaerobic incubation followed for the SBA plates at $37^{\circ} \mathrm{C}$ and were evaluated after 48 and $72 \mathrm{~h}$. Taxonomic classification of the potentially Staphylococcus sp. isolates followed by using routine microbiological procedures such as: colony morphology, Gram staining, catalase and oxidase reactions and coagulase test [free coagulase (Coagulase plasmaEDTA, bioMérieux, Lyon, France) and bound coagulase production (Staphylase test, bioMérieux, Lyon, France)]. After the basic microbiology, the Staphylococcus sp. isolates were processed by using VITEK-2 (bioMérieux, Lyon, France), according to the manufacturer's instructions. Finally, the strains were then frozen at $-80{ }^{\circ} \mathrm{C}$ in BHI broth (Oxoid Ltd., Basingstoke, UK) with 20\% glycerol.

- $\quad$ Enumeration of E. coli was carried out according to ISO 16649-2:2001 [34]. A 1-mL aliquot of each sample and series of 10- fold dilutions were set using peptone tryptone water (Condalab, Madrid, Spain) and were transferred into petri dishes, to which Tryptone Bile X-glucuronide medium (TBX; Oxoid, Hampshire, UK) was immediately added. Incubation at $44{ }^{\circ} \mathrm{C}$ for $24 \mathrm{~h}$ followed, and then the presumptive colonies were enumerated. The quantification limit was $1 \mathrm{CFU} / \mathrm{mL}$. The primary identification was carried out using API $20 \mathrm{E}$ (bioMerieux) and the identification was completed using the Vitek ${ }^{\circledR} 2$ system (bioMerieux, Marcy l'Etoile, France).

Antimicrobial Susceptibility Testing

The reference strains S. aureus ATCC 29213 and E.coli ATCC 25922 were used for quality control and were the first passage from ATCC's freeze-dried vial.

In the present study all stains which were identified as S. aureus or E. coli isolates were screened for susceptibility using the disk diffusion test which was performed and evaluated according to the guides of Clinical and Laboratory Clinical Institute (CLSI) [35]. The zone of inhibition was recorded in millimeters and results were interpreted [35].

- $\quad$ For S. aureus were used; ampicillin $(20 \mu \mathrm{g})$, erythromycin $(15 \mu \mathrm{g})$, tetracycline $(30 \mu \mathrm{g})$, clindamycin $(2 \mu \mathrm{g})$, ciprofloxacin $(10 \mu \mathrm{g})$, ceftiofur $(30 \mu \mathrm{g}$, 3rd generation cephalosporin), rifampicin $(5 \mu \mathrm{g})$, teicoplanin $(30 \mu \mathrm{g})$, pefloxacin $(10 \mu \mathrm{g})$, amoxicillin-clavulanate $(30 \mu \mathrm{g})$, streptomycin $(30 \mu \mathrm{g})$, gentamicin $(10 \mu \mathrm{g})$, cefuroxime $(20 \mu \mathrm{g})$, norfloxacin (NX-10 $\mu \mathrm{g}$ ), ceftriaxone $(25 \mu \mathrm{g})$, nalidixic acid (NA-30 $\mu \mathrm{g}$ ), vancomycin (VA-30 $\mu \mathrm{g}$ ), sulphamethoxazole-trimethoprim $(30 \mu \mathrm{g})$, chloramphenicol $(30 \mu \mathrm{g})$ and Cef (cefoxitin, $30 \mu \mathrm{g})$. 
All S.aureus isolates were evaluated for growth using the Oxacillin salt agar screen susceptibility test (OSAS).

The phenotypic identification of methicillin-resistant S. aureus (MRSA) was performed as follows: Coagulase-positive S. aureus (CoPS) isolates were first identified phenotypically by placing them on Mueller-Hinton agar plate containing $4 \% \mathrm{NaCl}$ and $6 \mu \mathrm{g} / \mathrm{mL}$ of oxacillin A second step included oxacillin-resistant isolates being placed on another freshly prepared Mueller-Hinton agar plate with $2 \mu \mathrm{g} / \mathrm{mL}$ of cefoxitin. All plates were incubated at $35^{\circ} \mathrm{C}$ for $18 \mathrm{~h}$ for both stages. Isolates that grew on the medium containing cefoxitin were considered as methicillin-resistant $S$. aureus (MRSA) [36].

- $\quad$ For E. coli isolates, the panel consisted of: ampicillin $(10 \mu \mathrm{g})$, amoxicillin-clavulanic acid $(20-10 \mu \mathrm{g})$, aztreonam $(30 \mu \mathrm{g})$, ceftiofur $(30 \mu \mathrm{g})$, streptomycin $(30 \mu \mathrm{g})$, cefotaxime $(5 \mu \mathrm{g})$, ceftazidime $(10 \mu \mathrm{g})$, chloramphenicol $(30 \mu \mathrm{g})$, cefepime $(30 \mu \mathrm{g})$, kanamycin $(30 \mu \mathrm{g})$, oxytetracycline $(30 \mu \mathrm{g})$, tetracycline $(30 \mu \mathrm{g})$, sulfamethoxazole-trimethoprim (23.75-1.25 $\mu \mathrm{g})$, enrofloxacin $(5 \mu \mathrm{g})$, and imipenem (10 $\mu \mathrm{g})$. In addition, E. coli isolates were tested for extended-spectrum beta-lactamase (ESBL) phenotype using a double-disk diffusion test, which is based on the synergy between third generation cephalosporins and clavulanate [37].

\subsection{Statistical Analysis}

Analyses were performed three times, except for those concerning Section 2.3.2, where only two repetitions have taken place. The chi square test was used to assess differences in residues among the stages of the lactation period (beginning, middle, end). Analysis of Variance with Tuckey's post hoc comparisons was used to test for differences of SCC and CNS Groups A and B. The Spearman correlation test was used to assess any correlation between various variables, e.g., SCC and CNS. Odds' ratio (OR) was calculated for positive samples to residues of antibiotics before and after heating of the sample. Analyses were performed using SPSS v20 (IBM Corp. Armonk, NY, USA) at a 95\% significance level.

\section{Results}

Table 1 shows the distribution of Somatic Cell Counts (SCC), Coagulase Negative Staphylococci (CNS) and true positive for residues of antibiotics samples, with respect to the month of the milking period.

Table 1. Distribution of average Somatic Cell Counts, average Coagulase Negative Staphylococci counts and true positive samples for residues of antibiotics, with respect to the month of the milking period and the group.

\begin{tabular}{|c|c|c|c|c|c|c|c|c|c|c|}
\hline \multirow{2}{*}{ Month } & \multicolumn{5}{|c|}{ Group A } & \multicolumn{5}{|c|}{ Group B } \\
\hline & SCC & CNS & Res. & S. aureus & E. coli & SCC & CNS & Res. & S. aureus & E. coli \\
\hline March & $5.33 \pm 0.42 \mathrm{ab}$ & $4.8 \pm 1.1^{\mathrm{c}}$ & 6 & $1.61 \pm 0.2$ & $1.62 \pm 0.38$ & $5.20 \pm 0.39^{d}$ & $6.08 \pm 0.57^{\mathrm{ab}}$ & 1 & $1.20 \pm 0.21$ & - \\
\hline April & $5.25 \pm 0.43 \mathrm{cab}$ & $4.9 \pm 0.9^{\mathrm{da}}$ & 2 & $1.34 \pm 0.2$ & - & $5.52 \pm 0.37^{\mathrm{a}}$ & $6.12 \pm 0.53^{b}$ & 0 & $1.20 \pm 0.21$ & - \\
\hline May & $5.28 \pm 0.49^{\mathrm{cb}}$ & $5.2 \pm 0.9^{\text {ca }}$ & 7 & - & $2.41 \pm 0.3$ & $5.77 \pm 0.31^{b}$ & $5.59 \pm 0.39 \mathrm{ab}$ & 3 & $1.36 \pm 0.20$ & - \\
\hline June & $5.42 \pm 0.36^{b}$ & $5.8 \pm 1.0^{\mathrm{b}}$ & 6 & - & - & $5.07 \pm 0.37^{c}$ & $6.35 \pm 0.39^{d}$ & 0 & - & - \\
\hline July & $5.05 \pm 0.40^{\mathrm{c}}$ & $5.3 \pm 0.7^{\mathrm{ca}}$ & 0 & - & $1.01 \pm 0.3$ & $5.04 \pm 0.64^{\mathrm{c}}$ & $5.16 \pm 0.37^{c}$ & 3 & $1.32 \pm 0.37$ & $1.81 \pm 0.2$ \\
\hline August & $5.14 \pm 0.47^{\text {ca }}$ & $5.4 \pm 0.8^{\mathrm{ab}}$ & 1 & - & $1.89 \pm 0.49$ & $5.22 \pm 0.24^{c}$ & $5.87 \pm 0.35^{\mathrm{a}}$ & 0 & - & - \\
\hline
\end{tabular}

SCC: in $10^{5}$ cells/mL; CNS, S aureus \& E. coli: in log cfu/Ml; Similar superscript letters in columns indicate no statistically significant differences (ANOVA with Tuckey's post hoc comparisons at 95\%); Res: true positive samples for residues of antibiotics/20 samples.

Group B represents the farms that follow a more traditional farming practice and let the animals graze with limited administration of additional concentrated feeds. As shown in Table 1, the somatic cells' count (SCC) values ranged from $5.05 \pm 0.4 \log$ cells $/ \mathrm{mL}$ in July to $5.42 \pm 0.5 \mathrm{log}$ cells $/ \mathrm{mL}$ in June. Although statistically significant differences were noted, these differences did not reveal a seasonal pattern except that by the end of the milking period (the last two months) the SCC values were lower than the ones in the beginning of 
the milking period (the first two months). Coagulase negative staphylococci (CNS) were isolated from milk samples throughout the whole milking period. The correlation between CNS counts and SCC counts were not significant $(p=0.95716)$. CNS counts did not differ significantly at the first three months of the milking period, but they suddenly increased in June, then they fell in July and then they increase again in August. The true positive tests for residues of antibiotics in milk samples, variate through the beginning, the middle and the end of the milking period without any statistical significance $\left(\chi^{2}=1.2137, p=0.545078\right.$, $\mathrm{df}=2$ ).

In Group A are included all the farms that employed more modern practices of farming such as the administration of concentrated feeds and machine milking. Table 1 shows the results of this group and reveals that the SCC counts range varied from $5.05 \pm 0.40 \log$ cells $/ \mathrm{mL}$ in July to $5.42 \pm 0.36 \log$ cells $/ \mathrm{mL}$ in June. Despite some statistically significant differences no clear seasonal pattern was observed, other than a gradual growth from April to June, then a sudden drop in July and a slight increase in August. The correlation of these counts to the counts of CNS was not significant $(p=0.95716)$. CNS counts increase suddenly in June, then they drop rapidly in July and then they significantly increase again in August. The true positive tests for residues of antibiotics significantly increase in the middle (May-June) and drop by the end (July-August) of the milking period $\left(\chi^{2}=12.1336\right.$, $p=0.002319, \mathrm{df}=2)$.

In a month-to-month comparison, SCC of group B are significantly higher than the ones of group A in April and May while in June the situation reverses, and group A's SCC are higher than those of group B (Figure 1). Likewise, when compared on a month-tomonth basis the CNS counts of the two groups, group B shows statistically significant higher counts every month except from July where no significant difference is noted (Figure 2).

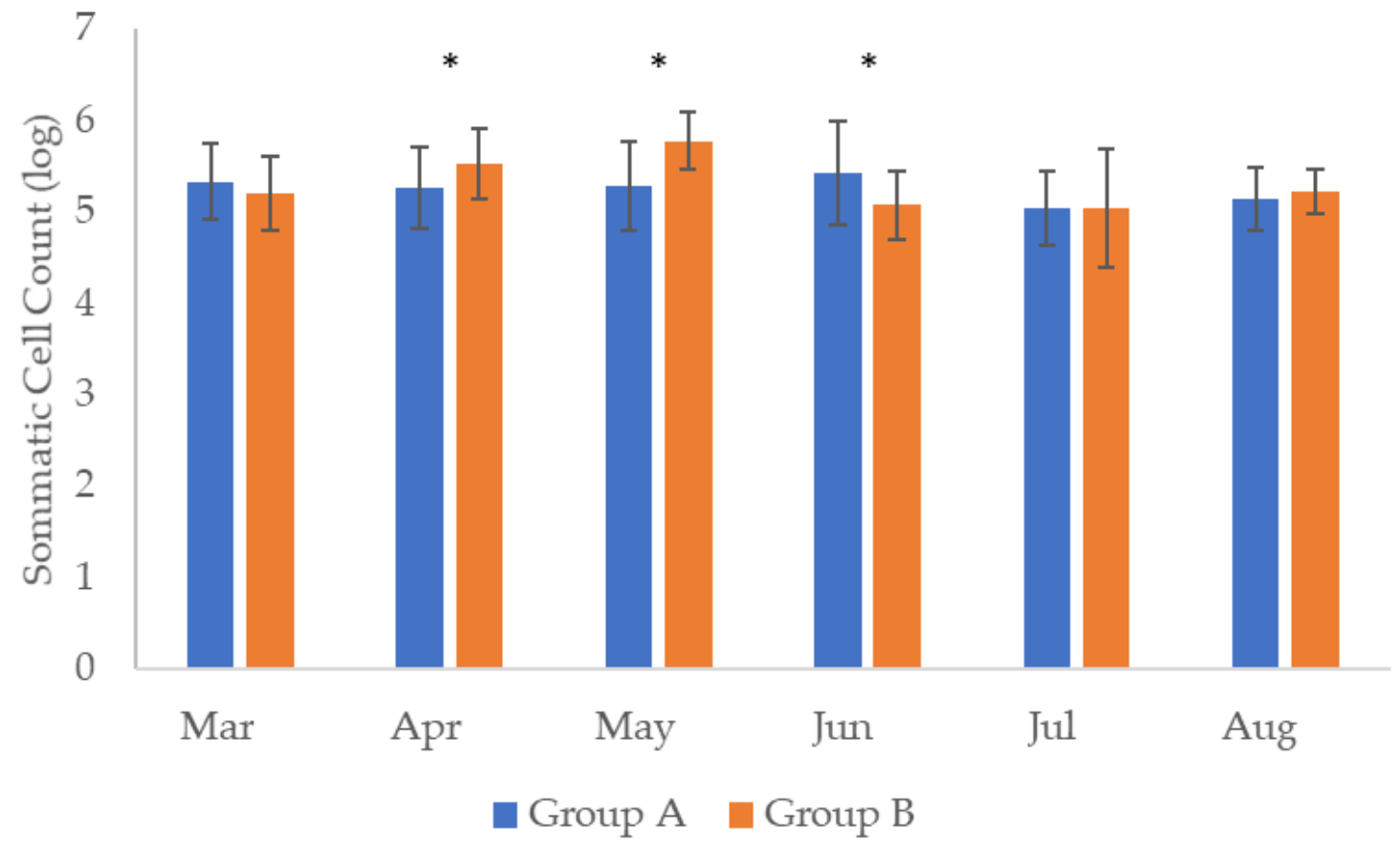

Figure 1. Comparison of somatic cell counts (SCC) between the samples of group A and B during the six months of observation (* denotes statistically significant differences between Group A \& B for the specific month according to ANOVA $p<0.05)$. 


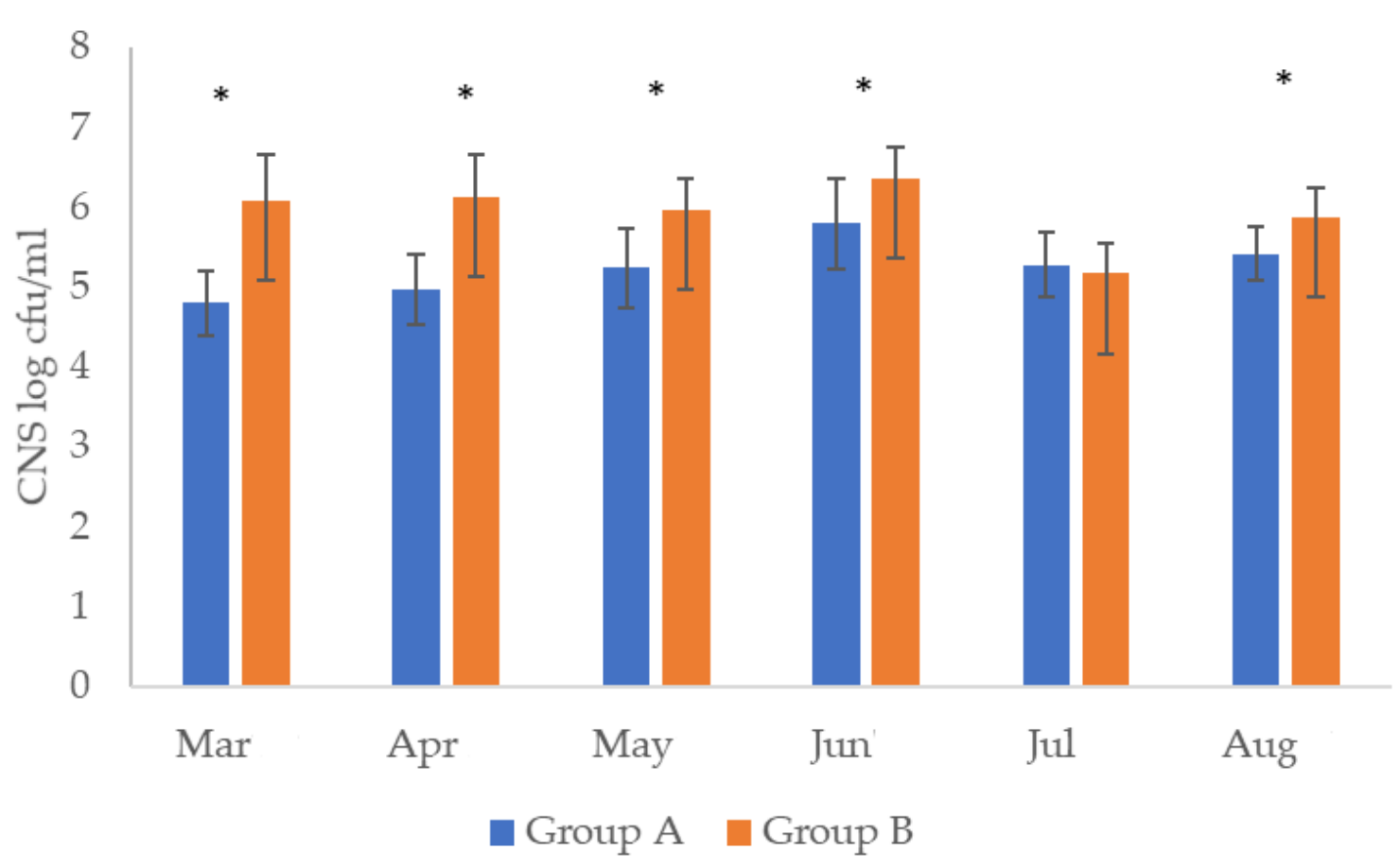

Figure 2. Comparison of Coagulase negative Staphylococci (CNS) counts between the samples of group A and B during the six months of observation (* denotes statistically significant differences between Group A \& B for the specific month according to ANOVA $p<0.05$ ).

In our study, once per month and for the whole milking period (March-August) a milk sample was tested from every bulk tank (20 tanks for group A and 20 tanks for group B). Every sample was first tested by 10 (ten) different methods (all of them based on the inhibition of growth principle) to escape the particularities of each method and then it was boiled and tested again. The samples which were found positive by at least one method after heating, were characterized as true positive (Table 2). Table 2 presents an interesting comparison. Group A shows 54 positives out of 120 samples before heating while Group B shows 42 out of 120 samples ( $45.00 \%$ and $35.00 \%$, respectively) before heating. After heating the percentage is $18.34 \%$ true positive samples for group A $(22 / 120)$ and $5.84 \%$ $(7 / 120)$ true positive samples for group B.

Table 2. Positive, true positive and false positive samples for antibiotics residues.

\begin{tabular}{|c|c|c|c|c|c|c|c|}
\hline \multicolumn{8}{|c|}{ Group A } \\
\hline & March & April & May & June & July & August & Total \\
\hline $\mathrm{BH}(+)$ & 9 & 7 & 15 & 11 & 4 & 8 & 54 \\
\hline $\mathrm{AH}(+)$ & 6 & 2 & 7 & 6 & 0 & 1 & 22 \\
\hline $\mathrm{FP}$ & 3 & 5 & 8 & 5 & 4 & 7 & 32 \\
\hline \multicolumn{8}{|c|}{ Group B } \\
\hline & March & April & May & June & July & August & Total \\
\hline $\mathrm{BH}(+)$ & 5 & 5 & 5 & 5 & 9 & 13 & 42 \\
\hline $\mathrm{AH}(+)$ & 1 & 0 & 3 & 0 & 3 & 0 & 7 \\
\hline $\mathrm{FP}$ & 4 & 5 & 2 & 5 & 6 & 13 & 35 \\
\hline
\end{tabular}

$\overline{\mathrm{BH}}(+)$ : positive samples before heating/20 samples, $\mathrm{AH}(+)$ : positive samples after heating (true positive) $/ 20$ samples, FP: false positive samples/20 samples.

S. aureus was isolated from two samples in group A in the beginning of the milking period and from four samples in group B, three of which in the first half of the milking 
period and one more in the middle of the second half. E. coli was isolated from 1 sample in group B and from four samples in group A, one every other month and one in August (Table 1).

According to the results of the susceptibility study, most of the S. aureus strains either from the group A or the group B were sensitive to the majority of antibiotics with few exceptions (Table 3). From the eight $S$. aureus isolates, two belonged in group $A$ and six in group B. Both isolates from group A proved multi resistant in 7 out of 21 drugs while those from group $B$ were sensitive (one strain), resistant in one or two antibiotics (four strains) and in one case in three. Seven E. coli strains from group A and one strain from group B were also screened for their susceptibility in 16 antibiotics. Almost all strains (except one) were multi resistant to at least three and up to seven antibiotics.

Table 3. Percentage of resistance to antibiotics of eight $S$. aureus and eight E. coli strains isolated from sheep and goat milk samples.

\begin{tabular}{|c|c|c|}
\hline Microorganism & Antibiotic & $\%$ Resistance \\
\hline \multirow{21}{*}{ S. aureus $(\mathrm{N}=8)$} & amoxicillin-clavulanate $(30 \mu \mathrm{g})$ & 12.5 \\
\hline & ampicillin $(20 \mu \mathrm{g})$ & 87.5 \\
\hline & ceftriaxone $(25 \mu \mathrm{g})$ & 0 \\
\hline & cefuroxime $(20 \mu \mathrm{g})$ & 0 \\
\hline & ceftiofur ( $30 \mu \mathrm{g}, 3$ rd generation cephalosporin) & 0 \\
\hline & ciprofloxacin $(10 \mu \mathrm{g})$ & 25 \\
\hline & clindamycin $(2 \mu \mathrm{g})$ & 0 \\
\hline & chloramphenicol $(30 \mu \mathrm{g})$ & 0 \\
\hline & cefoxitin $(30 \mu \mathrm{g})$ & 0 \\
\hline & erythromycin $(15 \mu \mathrm{g})$ & 0 \\
\hline & gentamicin $(10 \mu \mathrm{g})$ & 0 \\
\hline & nalidixic acid $(30 \mu \mathrm{g})$ & 0 \\
\hline & norfloxacin $(10 \mu \mathrm{g})$ & 25 \\
\hline & pefloxacin $(10 \mu \mathrm{g})$ & 0 \\
\hline & rifampicin $(5 \mu \mathrm{g})$ & 0 \\
\hline & streptomycin $(30 \mu \mathrm{g})$ & 12.5 \\
\hline & trimethoprim sulfamethoxazole $(23.75-1.25 \mu \mathrm{g})$ & 0 \\
\hline & teicoplanin $(30 \mu \mathrm{g})$ & 0 \\
\hline & tetracycline $(30 \mu \mathrm{g})$ & 62.5 \\
\hline & vancomycin $(30 \mu \mathrm{g})$ & 25 \\
\hline & $\begin{array}{l}\text { Morphological-phenotypic identification of } \\
\text { methicillin-resistant S. aureus (MRSA) }\end{array}$ & 37.5 \\
\hline
\end{tabular}


Table 3. Cont.

\begin{tabular}{|c|c|c|}
\hline Microorganism & Antibiotic & $\%$ Resistance \\
\hline \multirow{15}{*}{ E. $\operatorname{coli}(\mathbf{N}=8)$} & amoxicillin-clavulanic acid $(20-10 \mu g)$ & 75 \\
\hline & ampicillin $(10 \mu g)$ & 87.5 \\
\hline & aztreonam $(30 \mu \mathrm{g})$ & 0 \\
\hline & cefotaxime $(5 \mu \mathrm{g})$ & 0 \\
\hline & ceftiofur $(30 \mu \mathrm{g})$ & 0 \\
\hline & ceftazidime $(10 \mu \mathrm{g})$ & 0 \\
\hline & chloramphenicol $(30 \mu \mathrm{g})$ & 12.5 \\
\hline & enrofloxacin $(5 \mu \mathrm{g})$ & 0 \\
\hline & imipenem $(10 \mu \mathrm{g})$ & 12.5 \\
\hline & kanamycin $(30 \mu \mathrm{g})$ & 12.5 \\
\hline & oxytetracycline $(30 \mu \mathrm{g})$ & 50 \\
\hline & streptomycin $(30 \mu g)$ & 37.5 \\
\hline & sulfamethoxazole-trimethoprim $(23.75-1.25 \mu \mathrm{g})$ & 37.5 \\
\hline & tetracycline $(30 \mu \mathrm{g})$ & 75 \\
\hline & 3rd generation cephalosporins and clavulanate & 0 \\
\hline
\end{tabular}

\section{Discussion}

In the mountainous rural areas where the current survey took place, geography has shaped two different farming practices. Steep slopes, plains and valleys determine in obvious and subtle ways the animal husbandry.

Farms in the higher altitude are more remote and tend to be more traditional. The animals of these herds are of mixed breeding descending from autochthonous breeds. They are very well adapted to the harsh weather and are also very resistant to various diseases. It is for these reasons and certainly not their inferior productivity, which makes them ideal for this ecosystem. Their main source of nutrition is grazing the surrounding pastures which are rather meagre, and this factor poses an upper limit to the size of the herd. Additionally, a small amount of concentrate is provided every evening. Milking is performed manually.

The other type of farming is observed in the lower altitudes. There the pastures are greener and the distances smaller. The survival of the animals is not dependent on the environmental conditions. The animals are housed in better conditions, still graze all day long, but they also receive a rich nutritious supplement of hay and various concentrates, a fact which allows larger herds, superior breeding animals and milking parlours.

Regardless the type of farm milking, this is performed twice per day and the milk is stored in each farm's cooling bulk tank. The present survey is an attempt to address the question if the bulk tank milk reflects the differences in the type of farming with respect to various safety and quality issues.

In the market, quite a few commercial kits are available for the detection of the antibiotic residues in milk. They are sensitive to different groups of antimicrobial substances and their function is based on the same principle, that is the inhibition of bacterial growth in the presence of antimicrobial residues. It is a semiquantitative method in which the bacterial growth in negative samples is marked by change in the color of the substrate, while in positive ones there is no bacterial growth, and the color of the substrate remains unchanged [38]. Usually, the indicator organism is B. stearothermophilus, while bromocresol serves as the color index (remains purple in positive samples and turns yellow in the negative ones). However, one thing is the result, and another thing is the biological interpretation of the result. The inhibition of bacterial growth can be affected by other factors, which inhibit the bacterial growth and eventually lead to false positive results. Such factors are (i) the presence of natural substances in the milk such as the bacteriocins, (ii) 
higher somatic cells content of the milk and (iii) presence of detergents and disinfectants in the milk [39-42]. It is for these reasons that any positive results should be further confirmed by more sophisticated methods. False negative results occur in cases of test failure or in cases where the implicated antibiotic residue is out of the range of detection of a particular test. It follows that it is of utmost importance to detect the residues and the best place to undertake that is at the production site, in the milk of the bulk tank of the farm, before the milk reaches the dairy. For such a task the required test should be able to detect the residues in relatively low concentrations and it should be relatively simple, sensitive to a large range of antibiotics and reliable. In other words, a suitable test should be able to detect the residues at concentrations above the MRL (Maximum Residue Level) values as they are stated in the legislation, it should be simple enough to be performed by a relatively unskilled person belonging to the personnel of the farm (or with a minimal training) and it should be performed by a low-cost method (the equipment included) [23,43].

In the present study, group A has significantly more true positive samples than group $\mathrm{B}$ by a factor of $3\left(\chi^{2}=8.825, p=0.002971, \mathrm{df}=1\right)$ (Table 2$)$. Since all farms from which the milk originates are in the same rural ecosystem, factors attributed to the farming management are responsible for this differentiation $(\mathrm{OR}=3.624, \mathrm{CI} 95 \%$ : 1.484-8.847, $p=0.0047)$. The false positive samples in both groups are in similar percentages $(26.67 \%$ for group A and $29.17 \%$ for group B) and can be attributed to substances (e.g., peptides) from the grazing plants with antibacterial properties which exert inhibition of bacterial growth, to bacteriocins produced by the milk's natural flora, to high count of somatic cells or to disinfectants producing thus a false positive score.

In April and in May SCC were higher in the milk samples of group B, but the numbers of positive and true positive samples were lower in that group in comparison with group A. The hypothesis that various substances originating from the pasture are the causes of these results cannot be a strong point as both groups share the same ecosystem. The same holds for the bacteriocin hypothesis. The possibility that-for some reasons attributable to the microenvironment of some farms of the group A-some strains of the microbiota of the milk exerted exceptional bacteriocin production cannot be ruled out. This point is rather weak, since most farms showed true positive samples in random order and not every month or even most months of the milking period (which would be the case if these exceptional bacteriocin producing populations dominated the milk microbiota throughout the milking period). It is known that the milk microbial populations vary seasonally, but strains with such powerful bacteriocins would survive through competition in most circumstances.

Somatic cells count (SCC) represents a measurement for the evaluation of the quality of the milk, as well as a strong indication for inflammation of the udder. There is no legal threshold provided by the EU legislation concerning SCC in the raw milk of sheep and goats. Leitner et al. (2021) propose bulk tank cut off limits $2.5 \times 10^{6}$ cells $/ \mathrm{mL}$ for sheep and $3.5 \times 10^{6}$ cells $/ \mathrm{mL}$ for goats [44]. In our study average SCC ranged from $5.05 \times 10^{6}$ cells $/ \mathrm{mL}$ to $5.42 \times 10^{6}$ cells $/ \mathrm{mL}$ for group A and from $5.04 \times 10^{6}$ cells $/ \mathrm{mL}$ to $5.77 \times 10^{6}$ cells $/ \mathrm{mL}$ for group $\mathrm{B}$. These measurements are the arithmetic means of the counts of each of the 20 different milk tanks for each group and are close to the geometric average counts reported by Lianou et al. (2021) in Greek flocs, that is $0.488 \times 10^{6}$ cells $/ \mathrm{Ml}$ [45].

Besides bacterial mastitis, other factors contribute to higher SCC in milk bulk tanks. Higher counts are observed in the beginning and in the end of the milking period and are not associated with mastitis [46]. The body condition is negatively correlated to the SCC counts because of the effects of the malnutrition [45]. Imbalanced nutrition leads to deficiencies in minerals and vitamins and can predispose to inflammation of the mammary gland and thus affect the SCC in sheep [47]. Stressful situations, and particularly the acute ones, increase the SCC in healing and in infected mammary glands [48]. In our study most farms had livestock consisting of both ewes and goats. In sheep SCC are more valid as an index of subclinical or clinical mastitis than in goats [49] where often no significant differences are recorded between bacteriologically positive and bacteriologically negative udders [50,51]. Differences in flock management as well as in the milking type, season 
(month, year), resistance to antibiotics and dry therapy can also affect the SCC and cause significant variations among flocks and within the same flock [52]. All these factors as well as breed, parity, estrus, and vaccination [53] can explain the differences reported in Table 1 and in Figure 1.

It should be noted that the coefficient of variation of the average SCC values presented in Table 1 were low, ranging from $6.60 \%$ to $9.28 \%$ for group A and from $4.59 \%$ to $12.69 \%$ for group B. This finding in turn, indicates a low variation of the SCC among the bulk tanks every month. Furthermore, the average SCC values of group A are not significantly different from the ones of group B (Mann-Whitney $U=17, p=0.93624$ ).

$S$. aureus is classified among the most frequent bacterial causative agents of clinical mastitis in small ruminants [54-57]. The isolation frequencies in the present study were low: two strains out of 120 samples in group A and six strains out of 120 samples in group B. This finding must be attributed to the effective use of antibiotics since all farmers are aware of the clinical manifestation of mastitis and most of them act immediately. The two strains isolated from group A had multi resistant profiles against seven substances, while the other six strains from group B had lower resistance profiles since one strain was sensitive to all substances, two strains to one substance, two strains in two substances and one strain to three substances. Ampicillin and tetracycline were the substances with increased recorded resistance (against seven and five strains, respectively). This is not a surprise because these two antibiotics are the commonly used in Greece.

$E$ coli is a bacterium often associated with compromised hygiene of the milking process [58]. One strain was isolated from group B and 7 strains from group A out of 120 samples for every group. This low frequency implies that the hygiene of the milking process as well as the hygiene of the facilities, of the equipment, etc., are in a satisfactory level. Six of seven strains isolated from group A showed a multi resistant profile (three strains against seven substances, one strain against six substances, one strain against seven substances and one strain against three substances) while the sole strain isolated from group B was found multi resistant too. Ampicillin, Amoxicillin -clavulanic acid and tetracycline were the substances with the highest recorded resistance (seven, six and six strains, respectively) as in the case of $S$. aureus and for the same reason.

The two species were tested in different panel of antibiotics with only 6 common substances against which $E$. coli strains expressed increased resistance with respect to those of $S$ aureus, while all strains of both species were sensitive to ceftiofur.

A statistical correlation could not be established between the isolated strains resistance and other parameters such as season, SCC, or CNS counts. The reason for this can be attributed to the small size of the isolates. However, another possible explanation is that the resistance observed is a remainder of antibiotic abuse in the past. Even in the absence of disease (as the low SCC imply) the surviving strains carry the resistance conferred by past abuse or extensive use of antibiotics in previous years.

The $S$. aureus and E. coli resistant isolates were relatively few and scarce since they were originating from different farms. Molecular methods such as sequencing, and genotyping could reveal the genetic determinants of this resistance $[59,60]$. However, a further correlation between the phenotypical and the genotypical resistance as well as hierarchical cluster analysis it is doubtful if they could shed light on the origins of these genes, given the remoteness of most of these farms and the scarcity of the isolates.

The genus Staphylococcus consists of 47 species and 23 subspecies. Of these, 38 species belong to the Coagulase Negative Staphylococci (CNS) group. Additionally, newer reports state 53 species and 28 subspecies (www.bacterio.net (accessed on 2 December 2021) [61,62]) with the same number of CNS species. Although CNS species form a group, this group is not based on phylogenetic relationships but is rather defined by delimitation from the coagulase positive Staphylococci such as S. aureus [63].

There is a consensus among most authors that CNS are the major causative agent of subclinical mastitis (SCM), and they report various prevalence rates which variate from $4.0 \%$ to $50 \%[13,64-71]$. Their high prevalence is due to the subclinical character of the mastitis 
because they often go undetected [72,73]. CNS are present in the milking environment, on tools or on equipment, on the surface of the teat and on the hands of the personnel of the farm and cause infectious inflammation through the teat canal. The result of such an infection is mastitis characterized by increased SCC, reduction of milk yield, compromised lamb development, spontaneous abortions, and high mortality [74]. They form biofilms which act as barriers to the penetration of antibiotics and behave as a hazard to the action of phagocytes [63,69,75-77]. Not all CNS infections lead to inflammation and the outcome depends on the condition of the skin and of the mucous membranes as barriers to the infiltration of the bacteria. The immune system of the host is also an important parameter since the presence of the leucocytes is imperative for phagocytosis [78]. CNS often carry multiple pathogenic factors such as enterotoxins and toxic shock syndrome toxin -1 (TSST-1) which are located on mobile genetic elements and can be horizontally transferred to other strains and populations [79].

Thorberg et al. (2006) [80] isolated S. epidermidis and S. chromogenes from raw milk and from the skin of the farmers who milked the animals. The fact that the isolation of these microorganisms is more frequent from the hands than from the milk lead the authors to the conclusion that humans are a major source of infection of animals during milking. $S$. epidermidis is the dominant CNS species in subclinical mastitis [71,81]. Pilipčincová et al. (2010) regard S. caprae along with S. epidermidis to be the most common CNS species in sheep milk [82].

CNS infection of the udder results also to technological problems in cheese making due to increased protein loss through whey [83-85]. The casein is lost in increased quantities in the whey because it has been already degraded in the mammary gland. If the proportion of milk from infected animals is high in the bulk tank, then the increased losses of protein and fat lead to formation of cheese with softer and more elastic texture due to the higher water content [70]. Subclinical mastitis reduces the lactose level of the milk causing impaired coagulation [86-90]. Despite these conclusions, it seems that not all CNS are technologically detrimental. Murgia et al. (2020) [91] recognize the CNS as beneficial bacteria contributing to the ripening or to the fermentation of meat products and while they exert protection against spoilage bacteria through the production of bacteriocin-like metabolites.

In the present study group B had significantly higher CNS counts in the bulk tank milk than group A (Mann-Whitney $\mathrm{U}=5, p=0.0455$ ) while the SCC counts were at the same level between the groups ( $p=0.93624)$. These findings suggest that the increased counts of CNS in group B are not associated with severe inflammation. The significantly fewer true positive samples of group B for antibiotic residues (OR $=3.6239$, CI 95\% 1.4844-8.8471, $p=0.0047$ ), further suggest that fewer antibiotics were needed in that group, and this leaves open the discussion of a possible protective role of CNS under certain circumstances. Besides bacteriocin-like substances [91] that CNS produce, S. epidermidis produces a serine protease which inhibits biofilm formation by S. aureus and prevents colonization [92]. The protective action of CNS to their host is still debatable and strain and species specific $[65,93,94]$.

\section{Conclusions}

- The bulk tank milk should be monitored on a regular basis for residues of antibiotics. The monitoring process should include at least two different types of tests and should be performed after heating the milk samples to avoid false positive tests;

- It seems that the type of small ruminant farming practice affects the CNS counts in the bulk tank milk. In the present study the group of traditional practice farms showed increased counts of CNS. Milk from such farms should be treated cautiously in the dairies, and instructions should be given to the farmers how to remedy the problem; S. aureus and E. coli were isolated in very low frequencies from both groups, without any statistical correlation with other parameters and with most strains being found multi resistant to antibiotics. These finding suggests that perhaps even in low prevalence and in absence of disease, these bacteria retain the resistance acquired in the past and thus play the role of reservoir. Such tests for susceptibility to antibiotics should be 
regularly performed to various microorganisms-indicators to monitor the resistance reservoir in the herd;

- CNS although incriminated as the most frequent cause of subclinical mastitis can also play a protective role depending on the strains and species involved. Such strainsif isolated and better understood- may have a role to play in the prevention and treatment of subclinical mastitis.

\begin{abstract}
Author Contributions: Conceptualization, G.R., I.S., A.T. (Athina Tzora) and C.V.; methodology, G.R., C.V., I.S., K.F. and A.T. (Athina Tzora); software, G.R. and A.A.; validation, C.V., A.T. (Athina Tzora) and E.B.; formal analysis, G.R., A.A. and A.T. (Athina Tzora); investigation, G.R., I.S. and K.F.; resources, G.R., K.F. and A.A.; data curation, G.R., A.T. (Athina Tzora) and A.A.; writing-original draft preparation, G.R., C.V., A.T. (Anastasios Tsinas), A.T. (Athina Tzora) and E.B.; writing-review and editing, C.V., A.T. (Athina Tzora), I.S. and E.B.; visualization, G.R. and C.V.; supervision, I.S., A.T. (Athina Tzora), A.T. (Anastasios Tsinas), E.B. and C.V.; project administration, A.T. (Athina Tzora) and C.V. All authors have read and agreed to the published version of the manuscript.
\end{abstract}

Funding: This research received no external funding.

Institutional Review Board Statement: Not applicable.

Informed Consent Statement: Not applicable.

Conflicts of Interest: The authors declare no conflict of interest.

\title{
References
}

1. Pappa, E.C.; Kondyli, E.; Sotirakoglou, K.; Bosnea, L.; Mataragas, M.; Allouche, L.; Tsiplakou, E.; Pappas, A.C. Farmers profile and characterization of sheep and goat dairy chain in Northwestern Greece. Sustainability 2021, 13, 833. [CrossRef]

2. Lai, G.; Pes, M.; Addis, M.; Pirisi, A. A cluster project approach to develop new functional dairy products from sheep and goat milk. Dairy 2020, 1, 154-168. [CrossRef]

3. Morales, F.D.A.R.; Genís, J.M.C.; Guerrero, Y.M. Current status, challenges and the way forward for dairy goat production in Europe. Asian-Australas. J. Anim. Sci. 2019, 32, 1256-1265. [CrossRef]

4. Balthazar, C.; Pimentel, T.; Ferrão, L.; Almada, C.; Santillo, A.; Albenzio, M.; Mollakhalili, N.; Mortazavian, A.; Nascimento, J.; Silva, M.; et al. Sheep milk: Physicochemical characteristics and relevance for functional food development. Compr. Rev. Food Sci. Food Saf. 2017, 16, 247-262. [CrossRef] [PubMed]

5. Csapó, Z.; Péntek, Á.; Riskó, T.C. Sensory evaluation and acceptance of goat yogurts in comparison with cow yogurts-An empirical study. In GSMAC 2019: Challenges and Opportunities to Develop Organizations Through Creativity, Technology and Ethics; Fotea, S., Fotea, I., Văduva, S., Eds.; Springer Proceedings in Business and Economics; Springer: Cham, Switzerland, 2020. [CrossRef]

6. Flis, Z.; Molik, E. Importance of bioactive substances in sheep's milk in human health. Int. J. Mol. Sci. 2021, 22, 4364. [CrossRef] [PubMed]

7. Pulina, G.; Milán, M.J.; Lavín, M.P.; Theodoridis, A.; Morin, E.; Capote, J.; Thomas, D.L.; Francesconi, A.H.D.; Caja, G. Invited review: Current production trends, farm structures, and economics of the dairy sheep and goat sectors. J. Dairy Sci. 2018, 101, 6715-6729. [CrossRef]

8. Katsouri, E.; Magriplis, E.; Zampelas, A.; Nychas, G.J.; Drosinos, E.H. Nutritional characteristics of prepacked feta PDO cheese products in Greece: Assessment of dietary intakes and nutritional profiles. Foods 2020, 9, 253. [CrossRef]

9. Katsouri, E.; Magriplis, E.; Zampelas, A.; Drosinos, E.H.; Nychas, G.-J. Dietary intake assessment of pre-packed graviera cheese in Greece and nutritional characterization using the nutri-score front of pack label scheme. Nutrients 2021, 13, 295. [CrossRef]

10. Velčovská, Š.; Sadílek, T. Certification of cheeses and cheese products origin by EU countries. Br. Food J. 2015, 117, 1843-1858. [CrossRef]

11. Guyomard, H.; Bureau, J.-C.; Chatellier, V.; Detang-Dessemdre, C.; Dupraz, P.; Jacquet, F.; Reboud, X.; Requillart, V.; Soler, L.G.; Tysebaert, M. Research for AGRI Committee-The Green Deal and the CAP: Policy Implications to Adapt Farming Practices and to Preserve the EU's Natural Resources; European Parliament, Policy Department for Structural and Cohesion Policies: Brussels, Belgium, 2020. [CrossRef]

12. Leitner, G.; Merin, U.; Silanikove, N. Estimate of milk and curd yield loss of sheep and goats with intrammamary infection and its relation to somatic cell count. Small Rumin. Res. 2008, 74, 221-225. [CrossRef]

13. Vasileiou, N.G.C.; Cripps, P.J.; Ioannidi, K.S.; Chatzopoulos, D.C.; Gougoulis, D.A.; Sarrou, S.; Orfanou, D.C.; Politis, A.P.; Gonzalez-Valerio, T.C.; Argyros, S.; et al. Extensive countrywide field investigation of subclinical mastitis in sheep in Greece. J. Dairy Sci. 2018, 101, 7297-7310. [CrossRef] [PubMed]

14. Silanikove, N.; Merin, U.; Leitner, G. On effects of subclinical mastitis and stage of lactation on milk quality in goats. Small Rumin. Res. 2014, 122, 76-82. [CrossRef] 
15. Vanderhaeghen, W.; Piepers, S.; Leroy, F.; Van Coillie, E.; Haesebrouck, F.; De Vliegher, S. Invited review: Effect, persistence, and virulence of coagulase-negative Staphylococcus species associated with ruminant udder health. J. Dairy Sci. 2014, 97, 5275-5293. [CrossRef] [PubMed]

16. Riggio, V.; Portolano. B. Genetic selection for reduced somatic cell counts in sheep milk: A review. Small Rumin. Res. 2015, 126, 33-42. [CrossRef]

17. Beltrán Martínez, M.C. Analytical Strategy for the Detection of Antibiotic Residues in Milk from Small Ruminants. Ph.D. Thesis, Universitat Politècnica de València, Valencia, Spain, 2014. [CrossRef]

18. Mahmoudi, R.; Asadpour, R.; Alamoti, M.P.; Golchin, A.; Kiyani, R.; Mohammadpour, R.; Pour, R.M. Raw cow milk quality: Relationship between antibiotic residue and Somatic cell count. Int. F. Res. J. 2013, 20, 3347-3350. Available online: http:/ /www. ifrj.upm.edu.my/20\%20(06)\%202013/54\%20IFRJ\%2020\%20(06)\%202013\%20Rohman\%20Mahmoudi\%20217.pdf (accessed on 20 November 2021).

19. Okocha, R.C.; Olatoye, I.O.; Adedeji, O.B. Food safety impacts of antimicrobial use and their residues in aquaculture. Public Health Rev. 2018, 39, 21. [CrossRef] [PubMed]

20. Sachi, S.; Ferdous, J.; Sikder, M.H.; Hussani, S.A.K. Antibiotic residues in milk: Past, present, and future. J. Adv. Vet. Anim. Res. 2019, 6, 315-332. [CrossRef]

21. Ricci, A.; Allende, A.; Bolton, D.; Chemaly, M.; Davies, R.; Fernández - Escámez, P.S.; Girones, R.; Koutsoumanis, K.; Lindqvist, R.; EFSA Panel on Biological Hazards (BIOHAZ); et al. Risk for the development of Antimicrobial Resistance (AMR) due to feeding of calves with milk containing residues of antibiotics. EFSA J. 2017, 27, e04665. [CrossRef]

22. European Commission, Food Safety. Residues of Veterinary Medicinal Products. Available online: https://ec.europa.eu/food/ safety/chemical-safety/residues-veterinary-medicinal-products_en (accessed on 2 December 2021).

23. Prabha, M.A.; Dharini, V.; Aishwarya, B.; Jaswanth, M.; Allan, S.; Selvam, S.P.; Kumar, M.M. Detection of antibiotic residues in food using biosensors. Asian J. Chem. 2021, 33, 1699-1708. [CrossRef]

24. Ndgung'u, T.W.; Omwamba, M.; Muliro, P.S. Evaluation of rapid beta-lactam antibiotic residues detection kits for raw milk. AJFS 2021, 15, 353-359. [CrossRef]

25. Kurjogi, M.; Issa Mohammad, Y.H.; Alghamdi, S.; Abdelrahman, M.; Satapute, P.; Jogaiah, S. Detection and determination of stability of the antibiotic residues in cow's milk. PLoS ONE 2019, 14, e0223475. [CrossRef]

26. Pietschmann, J.; Dittmann, D.; Spiegel, H.; Krause, H.J.; Schröper, F. A novel method for antibiotic detection in milk based on competitive magnetic immunodetection. Foods 2020, 30, 1773. [CrossRef]

27. Layada, S.; Benouareth, D.E.; Coucke, W.; Andjelkovic, M. Assessment of antibiotic residues in commercial and farm milk collected in the region of Guelma (Algeria). Int. J. Food Contam. 2016, 3, 19. [CrossRef]

28. Yamani, M.I.; Al-Kurdi, L.M.; Haddadin, M.S.Y.; Robinson, R.K. A simple test for the detection of antibiotics and other chemical residues in ex-farm milk. Food Control 1999, 10, 35-39. [CrossRef]

29. Tumini, E.; Herrera-Moyano, E.; San Martín-Alonso, M.; Barroso, S.; Galmarini, C.M.; Aguilera, A. The antitumor drugs trabectedin and lurbinectedin induce transcription-dependent replication stress and genome instability. Mol. Cancer Res. 2019, 17, 773-782. [CrossRef]

30. Almashhadany, D.A. Screening of antibiotic residues in raw milk of cows and buffalos by diffusion assays. Italy J. Food Saf. 2021, 10, 9034. [CrossRef] [PubMed]

31. Vyletělová, M.; Vlková, H.; Manga, I. Occurrence and characteristics of methicillin resistant Staphylococcus aureus and methicillin resistant coagulase-negative staphylococci in raw milk manufacturing. Czech J. Food Sci. 2011, 29, S11-S16. [CrossRef]

32. Moura, G.S.; Gebreyes, W.A.; Marques, M.F.S.; Stipp, D.T.; Souza, F.N.; Da Costa, L.B.; Oliveira, C.J.B. Short communication: Occurrence of methicillin-resistant Staphylococcus aureus and coagulase-negative staphylococci in dairy goat herds in Ohio, United States. J. Dairy Sci. 2018, 101, 7804-7807. [CrossRef]

33. Zangerl, P.; Asperger, H. Chapter 6 Media used in the detection and enumeration of Staphylococcus aureus. In Progress in Industrial Microbiology; Janet, E.L., Corry, G.D.W., Baird, C.R.M., Eds.; Elsevier: Amsterdam, The Netherlands, 2003; Volume 37, pp. 91-110. [CrossRef]

34. International Organization for Standardization. Microbiology of Food and Animal Feeding Stuffs-Horizontal Method for the Enumeration of Beta-Glucuronidase-Positive Escherichia Coli-Part 2: Colony-Count Technique at 44 Degrees C Using 5-Bromo-4-Chloro-3-Indolyl Beta-D-Glucuronide; International Organization for Standardization: Geneva, Switzerland, 2010; ISO 16649-2.

35. CLSI. Performance Standards for Antimicrobial Disk Susceptibility Tests, Approved Standard, 7th ed.; CLSI Document M02-A11; Clinical and Laboratory Standards Institute: Pittsburgh, PA, USA, 2012.

36. Kali, A.; Stephen, S.; Umadevi, S. Laboratory evaluation of phenotypic detection methods of methicillin-resistant Staphylococcus aureus. Biomed J. 2014, 37, 411-414. [CrossRef]

37. Rawat, D.; Nair, D. Extended-spectrum $\beta$-lactamases in gram negative bacteria. J. Glob. Infect. Dis. 2010, 2, 263-274. [CrossRef]

38. Kivirand, K.; Kagan, M.; Rinken, T. Biosensors for the detection of antibiotic residues in milk. Biosens.-Micro Nanoscale Appl. 2015, 16, 425-456. [CrossRef]

39. Kang, J.H.; Jin, J.H.; Kondo, F. False-positive outcome and drug residue in milk samples over withdrawal times. J. Dairy Sci. 2005, 88, 908-913. [CrossRef]

40. Kang, J.H.; Kondo, F. Occurrence of false-positive results of inhibitor on milk samples using the Delvotest SP assay. J. Food Prot. 2001, 64, 1211-1215. [CrossRef] 
41. Cardoso, C.V.; de C Nunes, E.L.; Barbosa, E.V. Ribeiro, A.d. G.P.; Souza, G.d.M.; Liberal, M.H.T.; Castro, H.C. Farm test for rapid identification of antibiotic residues in raw milk. Adv. Biotech. Microbiol. 2019, 13, 555853. [CrossRef]

42. Romero, T.; Beltrán, M.C.; Althaus, R.L.; Molina, M.P. Interference of non-specific detergents in microbial inhibitor test results for screening antibiotics in goat's milk. J. Appl. Anim. Res. 2017, 45, 159-163. [CrossRef]

43. Wu, Q.; Zhu, Q.; Liu, Y.; Shabbir, M.A.B.; Sattar, A.; Peng, D.; Tao, Y.; Chen, D.; Wang, Y.; Yuan, Z. A microbiological inhibition method for the rapid, broad-spectrum, and high-throughput screening of 34 antibiotic residues in milk. J. Dairy Sci. 2019, 102, 10825-10837. [CrossRef] [PubMed]

44. Leitner, G.; Lavon, Y.; Matzrafi, Z.; Benun, O.; Bezman, D.; Merin, U. Somatic cell counts, chemical composition and coagulation properties of goat and sheep bulk tank milk. Int. Dairy J. 2016, 58, 9-13. [CrossRef]

45. Lianou, D.T.; Michael, C.K.; Vasileiou, N.G.C.; Petinaki, E.; Cripps, P.J.; Tsilipounidaki, K.; Katsafadou, A.; Fthenakis, G.C. Extensive countrywide field investigation of somatic cell counts and total bacterial counts in bulk-tank raw milk in sheep flocks in Greece. Foods 2021, 10, 268. [CrossRef] [PubMed]

46. Paape, M.J.; Wiggans, G.R.; Bannerman, D.D.; Thomas, D.L.; Sanders, A.H.; Contreras, A.; Moroni, P.; Miller, R.H. Monitoring goat and sheep milk somatic cell counts. Small Rumin. Res. 2007, 68, 114-125. [CrossRef]

47. Nudda, A.; Atzori, A.S.; Correddu, F.; Battacone, G.; Lunesu, M.F.; Cannas, A.; Pulina, G. Effects of nutrition on main components of sheep milk. Small Rumin. Res. 2020, 184, 106015. [CrossRef]

48. Mehdid, A.; Martí-De Olives, A.; Fernández, N.; Rodríguez, M.; Peris, C. Effect of stress on somatic cell count and milk yield and composition in goats. Res. Vet. Sci. 2019, 125, 61-70. [CrossRef]

49. Persson, Y.; Olofsson, I. Direct and indirect measurement of somatic cell count as indicator of intramammary infection in dairy goats. Acta Vet. Scand. 2011, 53, 15. [CrossRef]

50. Min, B.R.; Tomita, G.; Hart, S.P. Effect of subclinical intramammary infection on somatic cell counts and chemical composition of goats' milk. J. Dairy Res. 2007, 74, 204-210. [CrossRef]

51. Hussein, H.A.; Fouad, M.T.; Abd El-Razik, K.A.; Abo El-Maaty, A.M.; D'Ambrosio, C.; Scaloni, A.; Gomaa, A.M. Study on prevalence and bacterial etiology of mastitis, and effects of subclinical mastitis and stage of lactation on SCC in dairy goats in Egypt. Trop. Anim. Health Prod. 2020, 52, 3091-3097. [CrossRef] [PubMed]

52. Gonzalo, C.; Carriedo, J.A.; García-Jimeno, M.C.; Pérez-Bilbao, M.; de la Fuente, L.F. Factors influencing variation of bulk milk antibiotic residue occurrence, somatic cell count, and total bacterial count in dairy sheep flocks. J. Dairy Sci. 2010, 93, 1587-1595. [CrossRef] [PubMed]

53. Raynal-Ljutovac, K.; Pirisi, A.; de Crémoux, R.; Gonzalo, C. Somatic cells and goat and sheep milk: Analytical, sanitary, productive and technological aspects. Small Rumin. Res. 2007, 68, 126-144. [CrossRef]

54. Andrade, N.C.; Laranjo, M.; Costa, M.M.; Queiroga, M.C. Virulence factors in Staphylococcus associated with small ruminant mastitis: Biofilm production and antimicrobial resistance genes. Antibiotics 2021, 10, 633. [CrossRef]

55. Romanò, A.; Gazzola, A.; Bianchini, V.; Cortimiglia, C.; Maisano, A.M.; Cremonesi, P.; Graber, H.U.; Vezzoli, F.; Luini, M. Staphylococcus aureus from goats are genetically heterogeneous and distinct to bovine ones. Front. Vet. Sci. 2020, 7, 628. [CrossRef]

56. Skoufos, I.; Giannenas, I.; Karamoutsios, A.; Tsinas, A.; Papadopoulos, G.K.; Tzora, A. Milk quality characteristics of indigenous sheep breeds Boutsko, Frisarta and Karagouniko. J. Hellenic Vet. Med. Soc. 2017, 68, 59-66. [CrossRef]

57. Fotou, K.; Tzora, A.; Voidarou, C.; Alexopoulos, A.; Plessas, S.; Avgeris, I.; Demertzis, P.G.; Bezirtzoglou, E.; Demertzi-Akrida, K. Isolation of microbial pathogens of Subclinical Mastitis from raw sheep's milk of Epirous (Greek) and their role in its hygiene. Anaerobe 2011, 17, 315-319. [CrossRef]

58. Condoleo, R.; Giangolini, G.; Chiaverini, A.; Patriarca, D.; Scaramozzino, P.; Mezher, Z. Occurrence of Listeria monocytogenes and Escherichia coli in raw sheep's milk from farm bulk tanks in central Italy. J. Food Prot. 2020, 83, 1929-1933. [CrossRef] [PubMed]

59. Osman, K.M.; Kappell, A.D.; Elhadidy, M.; ElMougy, F.; El-Ghany, W.A.A.; Orabi, A.; Mubarak, A.S.; Dawoud, T.M.; Hemeg, H.A.; Moussa, I.M.I.; et al. Poultry hatcheries as potential reservoirs for antimicrobial-resistant Escherichia coli: A risk to public health and food safety. Sci. Rep. 2018, 11, 5859. [CrossRef] [PubMed]

60. Hailu, W.; Helmy, Y.A.; Carney-Knisely, G.; Kauffman, M.; Fraga, D.; Rajashekara, G. Prevalence and antimicrobial resistance profiles of foodborne pathogens isolated from dairy cattle and poultry manure amended farms in Northeastern Ohio, the United States. Antibiotics 2021, 10, 1450. [CrossRef] [PubMed]

61. Vasileiou, N.G.C.; Chatzopoulos, D.C.; Sarrou, S.; Fragkou, I.A.; Katsafadou, A.I.; Mavrogianni, V.S.; Petinaki, E.; Fthenakis, G.C. Role of staphylococci in mastitis in sheep. J. Dairy Res. 2019, 86, 254-266. [CrossRef]

62. Tonamo, A.; Komlósi, I.; Varga, L.; Kačániová, M.; Peles, F. Identification of ovine-associated staphylococci by MALDI-TOF mass spectrometry. Acta Aliment. 2021, 50, 210-218. [CrossRef]

63. Becker, K.; Heilmann, C.; Peters, G. Coagulase-negative staphylococci. Clin. Microbiol. Rev. 2014, 27, 870-926. [CrossRef] [PubMed]

64. Fthenakis, G.C. Prevalence and aetiology of subclinical mastitis in ewes of Southern Greece. Small Rumin. Res. 1994, 13, 293-300. [CrossRef]

65. Pyörälä, S.; Taponen, S. Coagulase-negative staphylococci-emerging mastitis pathogens. Vet. Microbiol. 2009, 134, 3-8. [CrossRef]

66. Virdis, S.; Scarano, C.; Cossu, F.; Spanu, V.; Spanu, C.; De Santis, E.P. Antibiotic resistance in Staphylococcus aureus and coagulase negative staphylococci isolated from goats with subclinical mastitis. Vet. Med. Int. 2010, 2010, 517060. [CrossRef] 
67. Zigo, F.; Sasáková, N.; Gregová, G.; Výrostková, J.; Ondrašovicová, S. Effects of using an alternative bedding composition on the levels of indicator microorganisms and mammary health in dairy farm conditions. Agriculture 2020, 10, 245. [CrossRef]

68. Zigo, F.; Vasil, M.; Ondrašovičová, S.; Výrostková, J.; Bujok, J.; Pecka-Kielb, E. Maintaining optimal mammary gland health and prevention of mastitis. Front. Vet. Sci. 2021, 8, 607311. [CrossRef]

69. Martins, K.B.; Faccioli, P.Y.; Bonesso, M.F.; Fernandes, S.; Oliveira, A.A.; Dantas, A.; Zafalon, F.; Cunha, M.L.; Maria de Lourdes, R.S. Characteristics of resistance and virulence factors in different species of coagulase-negative staphylococci isolated from milk of healthy sheep and animals with subclinical mastitis. J. Dairy Sci. 2017, 100, 2184-2195. [CrossRef] [PubMed]

70. Leitner, G.; Lavon, Y.; Merin, U.; Jacoby, S.; Blum, S.E.; Krifucks, O.; Silanikove, N. Milk quality and milk transformation parameters from infected mammary glands depends on the infecting bacteria species. PLoS ONE 2019, 14, e0213817. [CrossRef] [PubMed]

71. Turchi, B.; Bertelloni, F.; Marzoli, F.; Cerri, D.; Tola, S.; Azara, E.; Longheu, C.M.; Tassi, R.; Schiavo, M.; Cilia, G.; et al. Coagulase negative staphylococci from ovine milk: Genotypic and phenotypic characterization of susceptibility to antibiotics, disinfectants and biofilm production. Small Ruminant. Res. 2020, 183, 106030. [CrossRef]

72. Libera, K.; Konieczny, K.; Grabska, J.; Smulski, S.; Szczerbal, I.; Szumacher-Strabel, M.; Pomorska-Mól, M. Potential novel biomarkers for mastitis diagnosis in sheep. Animals 2021, 11, 2783. [CrossRef] [PubMed]

73. Dore, S.; Liciardi, M.; Amatiste, S.; Bergagna, S.; Bolzoni, G.; Caligiuri, V.; Cerrone, A.; Montagna, C.O.; Saletti, M.A.; Scatassa, M.L.; et al. Survey on small ruminant bacterial mastitis in Italy, 2013-2014. Small Rumin. Res. 2016, 141, 91-93. [CrossRef]

74. Pikhtirova, A.; Bujok, J.; Pecka-Kiełb, E.; Zachwieja, A.; Vasil, M.; Elečko, J.; Zigo, F. Fatty acid profile of ewe's milk infected with Staphylococcus spp. Iran. J. Vet. Res. 2020, 21, 216-220. [PubMed]

75. Pizauro, L.J.L.; de Almeida, C.C.; Soltes, G.A.; Slavic, D.; de Ávila, F.A.; Zafalon, L.F.; MacInnes, J.I. Short communication: Detection of antibiotic resistance, mecA, and virulence genes in coagulase-negative Staphylococcus spp. from buffalo milk and the milking environment. J. Dairy Sci. 2019, 102, 11459-11464. [CrossRef]

76. Vasil', M.; Farkašová, Z.; Elečko, J.; Zigo, F. Occurrence of resistance to antibiotics therapy in coagulase-positive and coagulasenegative Staphylococci isolated from sheep's milk in holding in Slovakia. Potravin. Slovak J. Food Sci. 2020, 14, 781-787. [CrossRef]

77. Katsafadou, A.I.; Politis, A.P.; Mavrogianni, V.S.; Barbagianni, M.S.; Vasileiou, N.G.; Fthenakis, G.C.; Fragkou, I.A. Mammary defenses and immunity against mastitis in sheep. Animals 2019, 9, 726. [CrossRef] [PubMed]

78. Murray, R.Z.; Kay, J.G.; Sangermani, D.G.; Stow, J.L. A role for the phagosome in cytokine secretion. Science 2005, 310, 1492-1495. [CrossRef] [PubMed]

79. Achek, R.; Hotzel, H.; Nabi, I.; Kechida, S.; Mami, D.; Didouh, N.; Tomaso, H.; Neubauer, H.; Ehricht, R.; Monecke, S.; et al. Phenotypic and molecular detection of biofilm formation in Staphylococcus aureus isolated from different sources in Algeria. Pathogens 2020, 9, 153. [CrossRef] [PubMed]

80. Thorberg, B.M.; Kühn, I.; Aarestrup, F.M.; Brändström, B.; Jonsson, P.; Danielsson-Tham, M.L. Pheno- and genotyping of Staphylococcus epidermidis isolated from bovine milk and human skin. Vet. Microbiol. 2006, 115, 163-172. [CrossRef] [PubMed]

81. Abbondio, M.; Fois, I.; Longheu, C.; Azara, E.; Tola, S. Biofilm production, quorum sensing system and analysis of virulence factors of Staphylococcus epidermidis collected from sheep milk samples. Small Rumin. Res. 2019, 174, 83-87. [CrossRef]

82. Pilipčincová, I.; Bhide, M.; Dudriková, E.; Trávniček, M. Genotypic characterization of coagulase-negative staphylococci isolated from sheep milk in Slovakia. Acta Vet. Brno 2010, 79, 269-275. [CrossRef]

83. Giadinis, D.; Arsenos, G.; Tsakos, P.; Psychas, V.; Dovas, C.I.; Papadopoulos, E.; Karatzias, H.; Fthenakis, G.C. “Milk-drop syndrome of ewes": Investigation of the causes in dairy sheep in Greece. Small Rumin. Res. 2012, 106, 33-35. [CrossRef]

84. Martí-De Olives, A.; Le Roux, Y.; Rubert-Alemán, J.; Peris, C.; Molina, M.P. Short communication: Effect of subclinical mastitis on proteolysis in ovine milk. J. Dairy Sci. 2011, 94, 5369-5374. [CrossRef]

85. Martí-De Olives, A.; Díaz, J.R.; Molina, M.P.; Peris, C. Quantification of milk yield and composition changes as affected by subclinical mastitis during the current lactation in sheep. J. Dairy Sci. 2013, 96, 7698-7708. [CrossRef]

86. Revilla, I.; Lurueña-Martínez, M.A.; Vivar-Quintana, A.M. Influence of somatic cell counts and breed on physico-chemical and sensory characteristics of hard ewes'-milk cheeses. J. Dairy Res. 2009, 76, 283-289. [CrossRef]

87. Revilla, I.; Rodríguez-Nogales, J.M.; Vivar-Quintana, A.M. Effect of somatic cell counts on ewes' milk protein profile and cheese-making properties in different sheep breeds reared in Spain. J. Dairy Res. 2009, 76, 210-215. [CrossRef] [PubMed]

88. Rovai, M.; Caja, G.; Salama, A.A.; Jubert, A.; Lázaro, B.; Lázaro, M.; Leitner, G. Identifying the major bacteria causing intramammary infections in individual milk samples of sheep and goats using traditional bacteria culturing and real-time polymerase chain reaction. J. Dairy Sci. 2014, 97, 5393-5400. [CrossRef] [PubMed]

89. Silanikove, N.; Merin, U.; Shapiro, F.; Leitner, G. Subclinical mastitis in goats is associated with upregulation of nitric oxidederived oxidative stress that causes reduction of milk antioxidative properties and impairment of its quality. J. Dairy Sci. 2014, 97, 3449-3455. [CrossRef]

90. Leitner, G.; Lavi, Y.; Merin, U.; Lemberskiy-Kuzin, L.; Katz, G. Online evaluation of milk quality according to coagulation properties for its optimal distribution for industrial applications. J. Dairy Sci. 2011, 94, 2923-2932. [CrossRef] [PubMed]

91. Murgia, M.A.; Deiana, P.; Nudda, A.; Correddu, F.; Montanari, L.; Mangia, N.P. Assessment of microbiological quality and physicochemical parameters of fruhe made by ovine and goat milk: A Sardinian (Italy) cheese. Fermentation 2020, 6, 119. [CrossRef] 
92. Iwase, T.; Uehara, Y.; Shinji, H.; Tajima, A.; Seo, H.; Takada, K.; Mizunoe, Y. Staphylococcus epidermidis Esp inhibits Staphylococcus aureus biofilm formation and nasal colonization. Nature 2010, 465, 346-349. [CrossRef]

93. Heilmann, C.; Ziebuhr, W.; Becker, K. Are coagulase-negative staphylococci virulent? Clin. Microbiol. Infect. 2019, 25, 1071-1080. [CrossRef]

94. Gosselin, V.B.; Dufour, S.; Middleton, J.R. Association between species-specific staphylococcal intramammary infections and milk somatic cell score over time in dairy goats. Prev. Vet. Med. 2020, 174, 104815. [CrossRef] [PubMed] 